\title{
REGIONALNI EKONOMSKI CIKLI KOT INSTRUMENT SONARAVNEGA REGIONALNEGA RAZVOJA NA PODEŽELJU
}

Pr. dr. Jörg Maier*

\section{Izvleček}

Prispevek obravnava teoretična izhodišča, prednosti in pomanjkljivosti regionalnih ekonomskih ciklov. Poseben poudarek je namenjen primerom delovanja omenjenih ciklov na Zgornjhem Frankovskem (Zvezna dežela Bavarska, Nemčija).

Ključne besede: regionalni ekonomski cikel, podeželje, Zgornja Frankovska, sonaravni regionalni razvoj.

\section{REGIONRAL ECONOMIC CYCLES AS AN INSTRUMENT OF A SUSTAINEBLE REGIONAL DEVELOPMENT IN RURAL AREAS}

\begin{abstract}
The article deals with theoretical starting-point, positive and negative aspects of regional economic cycles. The special empnasis has been put on good practice examples in Upper Franconia (Bavaria, Germany).

Key words: regional economic cycle, rural areas, Upper Franconia, sustain able regional development,
\end{abstract}

\footnotetext{
${ }^{\star}$ Pr. dr. Jörg Maier
} 


\section{Introduction: A change of paradigm in a theoretical and political perspective of regional development}

Starting in the 70ies, based on experiences in the so- called developing countries, a process of rethinking in the regional development theory and regional policy have taken place, mainly focused on Austria ${ }^{1}$ and on Bavaria ${ }^{2}$, since the beginning of the 80 ies. The practical state and regional policy picked up polarization- theoretical concepts, like the "Bottom- Up". This change of paradigm reached a certain peak with the transformation of the EU- structure funds in 1985 , e.g. with promoting rural areas using the possibilities of "Aim $5 b^{\prime \prime}$.

These have been typical strategies and measures of the regional policy for rural areas in the 80ies and 90ies:

- supporting co-operation of regional small- and medium sized enterprises (SME) for strengthening competition chances, of rationalization or improvements of regional demand;

- supporting initiatives of different groups of people for finding market niches, product innovations and new organization forms;

- creating innovation transfer and information exchanges up to the final aim of regional inventors' fairs;

- reducing equity capital problems especially during economic troughs with establishing regional capital sharing (interest) companies;

- promoting regional economic cycles with intensification of intraregional good flows and order exchanges.

In conjunction with the planned EU East- Enlargement there is a general reorientation of the EU regional policy scheduled in the "Agenda 2000". Therefore the German regional development policy is more and more focused on the program "LEADER+", concerning rural areas. There are main focuses on part 3 "Local Products and Services" in the establishing development plan with supporting concrete actions like these:

- supporting institutions for bundling up the supply,

- bundling up supplies of small - and medium sized enterprises (SME),

\footnotetext{
1 Glatz, H., Scheer, G., 1981, Neue Entwicklungsstrategien für strukturschwache ländliche Regionen", Wien.

2 Maier. J, Petzschner, E., Pfaller, G., von Wahl, D., Weber, J., 1982, Ąüberlegungen zu einer raumordnungspolitischen Konzeption für periphere Räume - das Beispiel Oberfranken", Sonderheft 1 der Arbeitsmaterialien zur Raumordnung und Raumplanung, Bayreuth.

3 Attenberger, J. (Publisher), 1998/Ein neuer Weg: Mehr Wertschöpfung durch Regionalmarketing und Stärkung regionaler Wirtschaftskreisläufe", Heft 21 of Bayerische Akademie Ländlicher Räume e.V., München.
} 
- supporting co-operation and institutions for marketing local products, like information- desks, export and marketing join- ventures,

- supporting establishing of institutions for joint sale of local products, e.g. in a mom-and-pop store,

- supporting introduction and development of cultivation of medicinal and herb plants,

- supporting diversification with taking up social, technical and commer cial activities as well as landscape conservation, tourism offers and other services,

- supporting pilot projects for marketing of local products from rural areas close by agglomeration areas,

- building up and protecting regional economic cycles with products from fields like landscape conservation and ecological cultivation.

But what does this mean for the local and regional development policy?

\section{Regional economic cycles: basic principles}

Demanding an improvement of the regional added value, therefore demanding regional economic cycles and quality improvements of the local products, is not new. Walter Isard had already collected such facts in the 50ies, which were more of an economical- structural kind. I had the chance to follow this problem in my dissertation in 1970, which concerned the example of the "Ostrachtal" and the methodical question after the registration of a local product with an original method. But it only became a demand after a special action of the Austrian Federal Chancellery in 1978 with a sure political- endogenous concept. It was put into reality in 38 test areas.

But why is this connected with problems on the other hand?

Now it's time to identify the term more precisely. In the economic theory, the term of "economic cycles" is described as a representation of economic relationships (output and financial transactions) between the aggregated units "private households", "enterprises", "state" and "foreign country". And it is seen as a result of division of labor. But in reality these product and capital flows between economic units are not, as described, closed, but open to their environment. Natural resources from the environment are reaching the economic cycles and harmful chemicals, often with less quality, are flowing back. These environmental flows are not corresponding to 
capital flows and environmental performance is not traded and reimbursed on markets. These are so- called "external effects". The negatives ones must be internalized, which means an inclusion in consumers' costaccountings.

\section{Aims of regional economic cycles}

Aims of regional economic cycles are on one hand reducing of raw material demand on the output side as well as reducing waste volume at the end of the consume process, and on the other hand covering regional demand as well as strengthening the regional identity.

The first step to reach these aims is the strengthening of the embodiment of product responsibility. At the end of their use time old products should be taken back by resellers and producers in order to be exploited, to improve or help develop new products. Therefore not just the products should be designed somehow to be possibly reintegrated into the production process, but also corresponding networks between producers, resellers and costumers should be created.

Figure 1: Regional economic cycle at present.

Skica 1: Regionalni ekonomski cikli-danes. 
Besides this a change of the perspective and a shift of the focus should be the next step in all three dimensions of the regional development - in ecological, economical and social dimension. In economical dimension, there should still be a focus on added value, but not at all costs and not onesided at the expenses of ecological and social necessities. The creation of intraregional economic cycles, which are based on regional co-operation and shoud be orientated towards a reducing of ecological and social crises as a result of the industrialization, is part of a sustainable economy. In this concept a special significance is attached to the aspects of regional production-, marketing- and processing- possibilities, the sustainable skimming of regional potential and the elimination of products at the end of the product life circle. Figure 1 shows the actual situation and describes a concentration of economical relationships between the region and the outside. The actual situation is characterized by a production of raw material and energy from outside the region, a small processing and marketing of intermediate products in the region and an export of final products. At the same time intermediate and final products, which mostly can be produced in the region, are imported.

Figure 2: Regional economic cycle in the future.

Skica 2: Regionalni ekonomski cikli-v prihodnosti. 
The budgeted situation (Figure 2) is characterized by a clear strengthening of the economical relationships inside the region. The marked arrows are describing all three aspects of sustainable regional development:

- all substances, which are used during the whole life circle, emitted in the production process or picked up as waste (ecological dimension);

- the life circle of a product and it's stations of added value and use (eco nomical dimension);

- the relationships of those, who are part of the production, the process ing, the consumption, the use and re-use and the waste disposal (social dimension).

\section{Advantages of regional economic cycles}

Regional economic cycles are support to reduction of transporting and the closing of material flows, guaranty overlook and controllability of developments inside the region and have positive effects on the regional labor market situation - demand and offer of workforce on a local and regional level could be combined. Economic cycles cover at least partly regional necessities and strengthen the regional identity and the cohesion of the inhabitants by putting the human and the community in the center of attention.

Regional economic cycles enable more efficient realization of the precaution-, person-responsible- and co-operation- principles. The regional orientation of the economy creates more transparence of the production circle and a bigger participation of social groups by formulation and achieving ecologic- political aims and measures in a way that intensively includes consumer and producer into product responsibility.

From the view of the enterprises more new forms of problem solving strategies arise from creating such economic cycles. Relationships are created, which are based on confidence, reciprocity and a mutual exchange for the use of all involved. Diverse relationships between different enterprises enable flexible reactions on unexpected occurrences and simplify the exchange of information and goods many times over. 


\section{Empirical examples of an implementation of regional economic cycles: regional context}

Which regions and potentials are especially suitable for building up regi-onal economic cycles?

First of all, notable regions have large resources of inexhaustibly raw material, regenerative energy, fossil fuel and so on. These primary resources can be used in regional economic cycles, especially for reprocessing, distribution, repair and re-use and in the same time they have certain consequences in education, further education and training. The sustainable use of wood in the area of Trier should be taken as an example here ${ }^{4}$. A similar significance have regions, in which meaningful interior orientation of economic activities are given - like in the fields of regional ground water supplying, waste disposal, feeding, living, energy supplying or health.

Regions with a specific know- how are very suitable for building up economic cycles and networks. Techniques and traditions can be developed in the sense of sustainable production and service.

Another category encloses areas, in which the awareness of structural problems is given or areas with possibilities for combining short-, mediumand long- term projects and perspectives. Mostly this are regions, in which long- term perspectives are realizable by fulfilling short- term steps and key persons have a great deal of influence on initiatives and projects.

\section{Empirical examples in the food processing industry}

Trying to formulate these argument more precisely, one should remember Spehl, who brought out several studies about the wood industry in "Rheinland- Pfalz" and the production and distribution of beef in 1993 and came to a result of high potential for regional economic cycles (see Fig. 3).

\footnotetext{
4 Spehl, H., 1994, Nachhaltige Regionalentwicklung, in: Band 212 der Arbeitsmaterialien der Akademie für Raumforschung und Landesplanung, Hannover, p. 69 - 89.
} 
Figure 3: Some information about wood production in Rheinland-Pfalz.

Skica 3: Proizvodnja lesa na območju Rheinland-Pfalz.

Source/ vir: Spehl, H., a.a.O., p. 51.

For the district of "Neumarkt" in the Bavarian district "Upper Palatia" Bätzing, Ermann and Scheu ${ }^{5}$ made a great research in the fields of market potential, regional self- supplying and regional input- output- relationships between different agricultural and commercial products. They find evidences for a regional self supply degree of $308 \%$ of milk and milk products in comparison with a $5 \%$ degree of the milk produced in the district and processed outside, which are finally coming back as final products. This is about $15 \%$ of the totally used milk in the whole district. In comparison with this, beef has a self supply degree of $337 \%$, pork $114 \%$ and lamb $125 \%$. About $10 \%$ of the districts' produced pork are actually eaten in the district, which is about $30 \%$ of the whole districts' pork use (see Figure 3 ).

This leads to the opinion that only a few of the numerous possibilities of regional economic cycles are used and the potential for an increase in regional added value is immense. The most important reason for this, is the large- scale structure of the distribution and the trade with extensive up to global function strategies, which are seldom integrate regional peculiarities.

5 Bätzing, W., Ermann, U., Scheu, K.,1999, Regional distribution of agricultural and commercial products in the district of Neumarkt in d. Opf., Erlangen- Neumarkt, especially p. 5. 
Figure 4: Production, Marketing, Distribution and Consumption of the produced cattle and calves resp. beef and veal.

Skica 4: Proizvodnja, trženje, distribucija in poraba (primer: govedo, meso).

Do thus exist real chances for small- and medium- sized enterprises, e.g. the baker's or the butcher's trade?

On the example of Upper- Franconian trade workshops Hacker ${ }^{6}$ tried to answer this question and came to the result, that the trade because of it's organizational and social structures posses ideal premises for the realization of regional economic cycles. But problematical is the fact that the number of trade workshops is constantly decreasing for years. Therefore in a long- term view there is fear that the "critical mass" of tradesman, which is necessary for realizing competitive co-operation, in some regions cannot still be reached. But just independent workshops inside the region are interested in regional problems and their solving with endogenous concepts. Especially critical is the number of mills, which are located at the key position of processing thus existentially important for the realization of regional concepts (see for example map 1 ).

6 Hacker, P., Regional economic cycles as an instrument of a sustainable endogenous economic policy- on the example of the food trade in the planning region Upper- Franconia, unreleased diploma- work at the Department of Economic Geography and Regional Planning at the University of Bayreuth, Bayreuth 2000 
Map 1: Number of enterprises of the food production within the sector of handicraftsmen in Upper Franconia in 1998.

Karta 1: Število živilsko-predelovalnih podjetij v sektorju obrt (Zgornja Frankovska dežela, 1998).

Source/vir: Bätznig, W., Ermann, U., Schen, K., a.a. O., p. 5

\section{REGIONAL ECONOMIC CYCLE}

\section{Summary}

Prispevek analizira spremembe $v$ orientaciji regionalnega razvoja $v$ zadnjih desetletjih. Še zlasti se osredotoča na določila Agende 2000 in programa LEADER+, namenjenega podeželju, $v$ katerem pomembno vlogo igra krepitev in varovbanje regionalnih ekonomskih ciklov.

Avtor poleg prednosti regionalnih ekonomskih cikolv zelo jasno analizira njihove pomanjklivosti in zlasti zadržanost makroekonomistov pri njihovem osnovanju.

S primeri iz Zgornje Frankovske, je prikazan spekter pozitivnih pokrajinskogospodarsko-razvojnih učinkov aktivnih regionalnih ekonomskih ciklov,, večinoma vezanih na živilsko-predelovalno in lesno industrijo.

Vendar - paradigma sonaravnega razvoja (kot osnovni princip Zakona o 
regionalnem planiranju $v$ Nemčiji od 1998) kliče po vzpostavljanju novih poti v regionalnem gospodarstvu, v vsaki niši globaliziranega gospodarstva. Ali znajo/bodo zmožni niši globaliziranega gospodarstva. Ali znajo/bodo zmožni regionalni ekonomski cikli ustrezno odreagiralti na te izzive?

\section{Limits of the development and criticism of demanding regional economic cycles}

The main focus is consequently on the aspects of the structural change with regard to the continuing globalization and the existing chances for regionalization. So fundamental criticism emerges mostly from the neoclassical economic policy, whose supporters identify the supporting of regional concepts as an intervention in the Market regulations and strictly reject it as a protectoral measure. Each form of supporting would just delay the structural change and the market oriented rebuilding of the regional economy, which leads in a macroeconomic view to prosperity loss. As market- economical they reject all influence on the local offer and rely on the self- regulating power of the market. But besides this, ecological and social components of the regional economy are neglected. Therefore they accept the "passive restoration to profitability" in the social field and linked with it a population decrease of a large dimension. Last but not least the Principle of Sustainability, as it is the fundamental principal of the Regional Planning Act in Germany since 1998, call upon to tread new paths of the regional economy, in the very niches of the globalized economy. 